\title{
Geothermal activity and epithermal gold mineralization in Japan
}

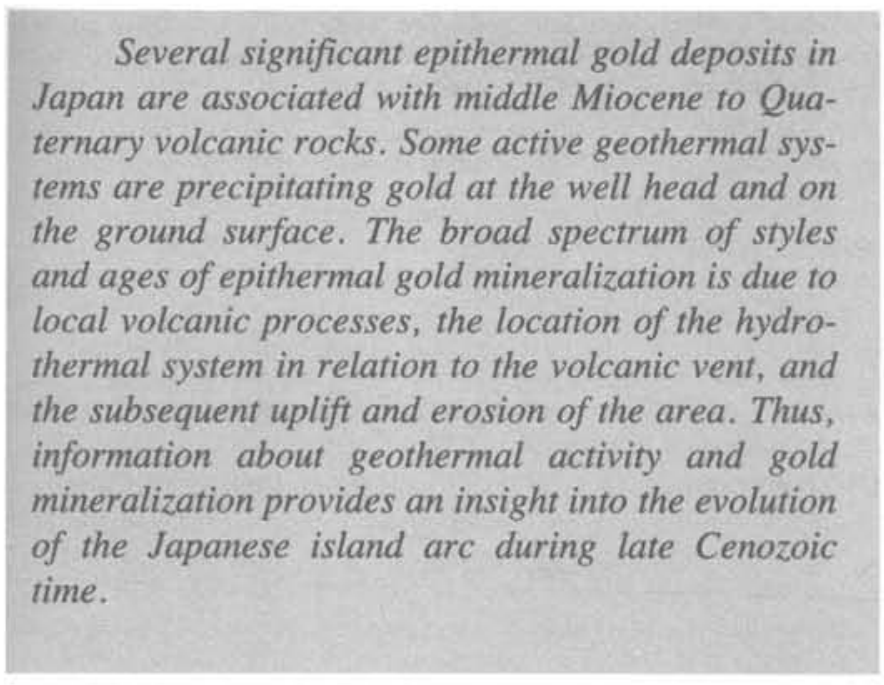

\section{Introduction}

Many active and extinct geothermal systems in Japan are closely related to late Cenozoic subaerial volcanism (fig. 1). Hyórothermal convection in the crustal thermal regime transported dissolved constituents, and subsequent precipitation took place in upper and cooler zones, so that epithermal mineral deposits formed, the extinct equivalents of today's geothermal systems. Epithermal gold was exploited by placer mining on Sado island as early as 1460, and vein gold production from several deposits peaked in the late 17th century, when about 2 metric tons of gold were exported annually from Japan. Thus, Japan has been known as a rich gold country because more than 500 metric tons of gold has been produced to date from epithermal gold deposits.

Geothermal development began in the early 1960 s at Otake on Kyushu and at Matsukawa in northeastern Japan. The first major power station ( 20 megawatts, MW) was completed at Matsukawa in 1966. Geothermal energy is used now for electricity generation and for space heating in many areas of Japan. The installed capacity of geothermal power production reached $270 \mathrm{MW}$ in 1990 (Higo and Esaki, 1990). The largest station is Hatchobaru (110 MW), located in north-central Kyushu (fig. 2). Data from detailed studies of active geothermal systems have been integrated and used to understand the process of ore formation in the epithermal environment.

Some active geothermal systems are precipitating gold at the well head of geothermal power stations, such as Okuaizu, and on the surface of hot springs, such as Osorezan. Waning or extinct geothermal systems are major sources of domestic gold production in Japan. Hishikari (250 metric tons of contained gold) is representative of such a gold deposit in a waning geothermal system.

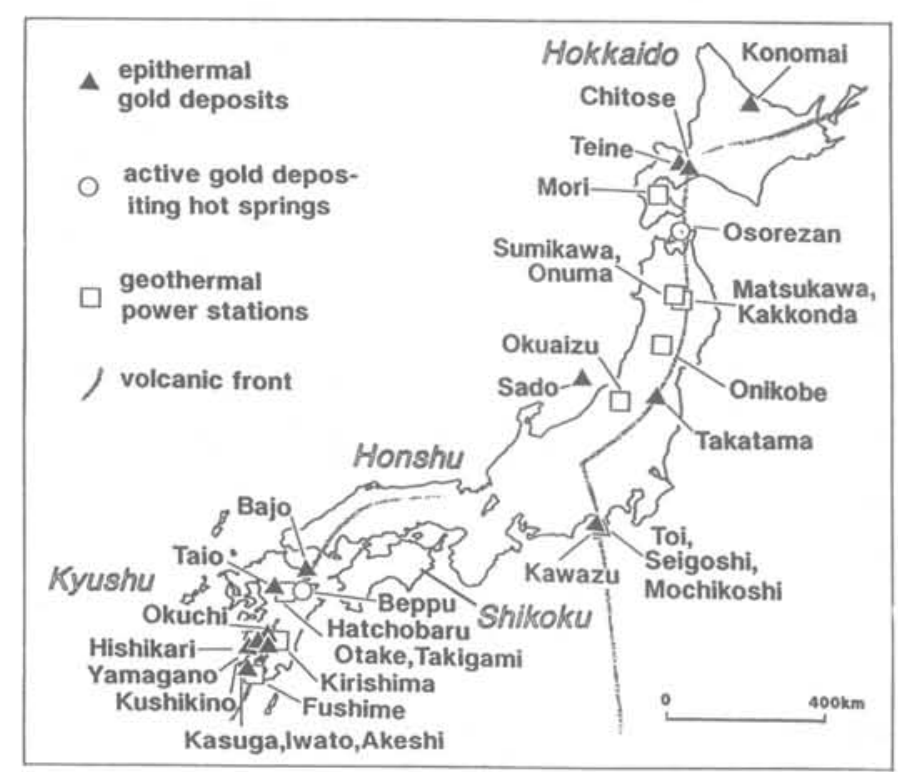

Figure 1.-The major geothermal system and epithermal gold deposits of Japan. Seven major geothermal power plants are in operation, and Sumikawa, Okuaizu, Takigami, Kirishima, and Fushime are sites of future development. Epithermal gold deposits are represented by gold mines or mining areas that have produced more than 10 metric tons of gold.

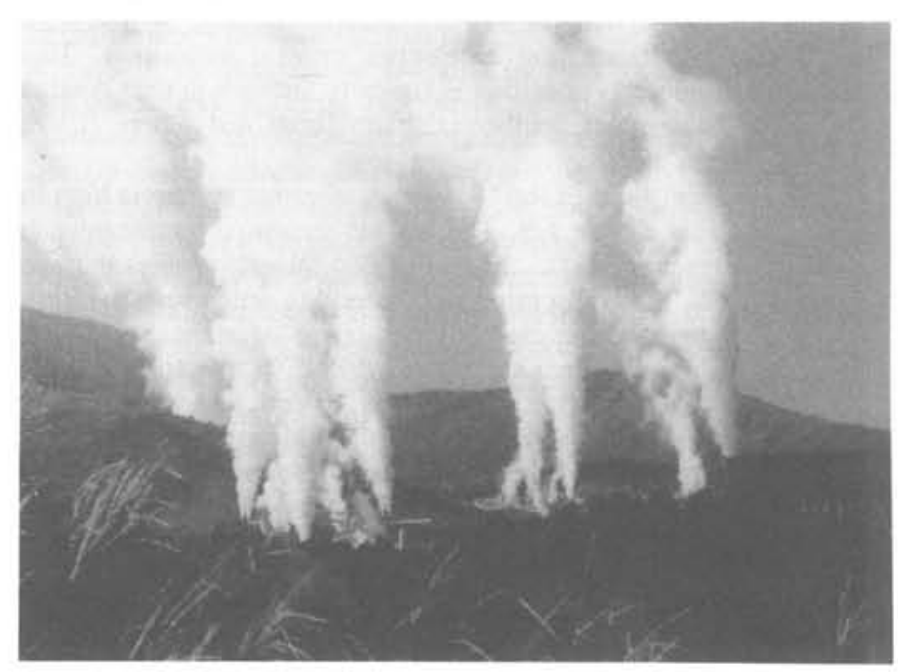

Figure 2.-Part of the Hatchobaru geothermal system (view to the south) showing steam discharge related to $55 \mathrm{MW}$ of electrical generation in the summer of 1984. Photograph by S. Taguchi. 
Table 1.-Range of chemical compositions of geothermal waters discharged from some production wells and Osorezan hot spring [Abbreviation: tr., trace. - , not determined]

\begin{tabular}{|c|c|c|c|c|c|c|c|c|c|c|c|c|c|}
\hline & Mori' & $\begin{array}{c}\text { Onuma } \\
\text { Sumikawa }^{2}\end{array}$ & Matsukawa $^{2}$ & Kakkonda $^{2}$ & Onikobe & Okuaizu ${ }^{4}$ & Takgami $^{5}$ & Otake & Hatchobaru ${ }^{6}$ & Kirishima? & Fushime & \multicolumn{2}{|c|}{$\begin{array}{l}\text { Osorezan } \\
\text { (hot spring) }\end{array}$} \\
\hline $\mathrm{pH}$ & $8.0-9.3$ & $7.1-7.6$ & $3.5-8.6$ & $8.5-9.1$ & 3.38 .1 & $6.3-8.0$ & $8.1-9.2$ & 67.8 .4 & $4.3-8.0$ & $2.4-9.4$ & $3.9-8.0$ & 6.8 & 70 \\
\hline $\begin{array}{l}\mathrm{SiO}_{2} \\
(\mathrm{mg} / \mathrm{l})\end{array}$ & $407-747$ & $410-619$ & $163-1987$ & $421-789$ & $360-690$ & $439-990$ & $365-661$ & $142-668$ & 509994 & $238-1036$ & $540-1250$ & 422 & 180 \\
\hline $\mathrm{Ca}$ & $3.4-25.5$ & $0-11$ & $6.4-301$ & $5.5-10.9$ & $120-520$ & $42-1750$ & $8.4-20.6$ & $8.4-30.4$ & $9.8-80$ & $5.6-30$ & $903-2480$ & 483 & 167 \\
\hline $\mathrm{Mg}$ & $0.1-4.7$ & - & $2.0-79.7$ & $0.01-0.34$ & $0.2-39$ & $0.1-20.8$ & $0.10-0.38$ & $2.3-14.4$ & $0.1-1.9$ & $0.0-4.8$ & $0.83-23.2$ & 0.52 & 41.1 \\
\hline $\mathrm{Na}$ & $3088-4660$ & $368-520$ & $80-800$ & $342-500$ & $960-1400$ & $2700-10600$ & $466-509$ & $670-1060$ & $1820-2590$ & $85-818$ & $7570-17400$ & 3830 & 835 \\
\hline K & $373-881$ & $53-62$ & $25-250$ & $34-63$ & $88-200$ & $180-2550$ & $47.1-89.0$ & $70-140$ & $289-383$ & $13.2-190$ & $1380-4970$ & 489 & 133 \\
\hline $\mathrm{SO}_{4}$ & $90-593$ & $102-221$ & $338-1855$ & $51-107$ & $20-92$ & $4.0-771$ & $95-252$ & $96-460$ & $54-266$ & $79.9-697$ & $<10-61$ & 48 & 327 \\
\hline $\mathrm{Cl}^{4}$ & $5260-7490$ & $499-693$ & $5.4-14.9$ & $428-692$ & $2290-5100$ & $6900-21800$ & $547-785$ & $460-1760$ & $2650-4475$ & $38-1180$ & $15000-32700$ & 6560 & 1380 \\
\hline $\mathrm{HCO}_{3}$ & - & $40-65$ & - & - & - & $4.3-956$ & $11-51$ & - & $5-57$ & $0-42.9$ & $<2-36$ & 69 & 635 \\
\hline $\mathrm{H}_{2} \mathrm{~S}$ & $0.0-9.8$ & - & - & tr. -6.1 & - & $\mathrm{tr}-1.5$ & - & - & - & tr $-18,2$ & - & 7.11 & 75. \\
\hline $\begin{array}{l}{ }^{1} \text { Yoshic } \\
{ }^{2} \text { Nakan } \\
{ }^{3} \text { Fujita }\end{array}$ & $\begin{array}{l}\text { da }(1981) \\
\text { mura and oth } \\
\text { (1991) }\end{array}$ & 81) & $\begin{array}{l}\text { "Goto } \\
{ }^{6} \text { Yuhar }\end{array}$ & $\begin{array}{l}\text { (1991) } \\
\text { ara and others }\end{array}$ & $(198 \mathrm{H})$ & $\begin{array}{l}8 \text { Akak } \\
{ }^{8} \text { Aoki }\end{array}$ & $\begin{array}{l}\text { (1988) } \\
\text { and Thompse }\end{array}$ & on $(1990)$ & & & & & \\
\hline
\end{tabular}

\section{Precipitation of gold-rich scale in geothermal plants}

Heavy-metal deposition from hydrothermal waters can occur in geothermal wells and surface pipelines. The initial fluid chemistry affects the capacity of the water for metal transport, and drastic changes in the physico-chemical conditions during flow in the pipelines will trigger mineral deposition. In general, high-chloride water tends to precipitate base metal sulfide scale, and high-sulfide water forms gold-rich scales. The range of chemical compositions is given in table 1 for the geothermal waters discharged from some production wells. Because geothermal waters tend to fractionate $\mathrm{CO}_{2}$ and $\mathrm{H}_{2} \mathrm{~S}$ nearly completely into the vapor phase on the way to the ground surface, the concentration of them is expected to be much higher in the reservoir. The chemical compositions of gold-bearing precipitates from geothermal waters are shown in table 2. Major deposition of precipitates often occurs in pipelines downstream of the well-head valve, as the pressure drop causes gas separation. The subsequent $\mathrm{pH}$ increase destabilizes the chloride complexes of base metals, whereas $\mathrm{H}_{2} \mathrm{~S}$ loss causes gold to deposit from sulfide complexes. Temperature drop is also significant and accelerates mineral deposition. This mechanism of mineral deposition is typically the case in the Okuaizu (also called Nishiyama) geothermal plant (Imai and others, 1988; Nitta and others. 1991)

The reservoir fluid of the Okuaizu geothermal system is high in chloride and very rich in gas. The highest measured temperature in the reservoir reaches $341{ }^{\circ} \mathrm{C}$. The identified mineral species that are deposited inside the well casing are alabandite, stibarsen, pyrargyrite, cubanite, tetrahedrite, chalcopyrite, galena, wurtzite, sphalerite, pyrrhotite, and pyrite (Imai and others, 1988). In the surface pipelines, silver-rich tetrahedrite, chalcopyrite, galena, and sphalerite are the major mineral species, along with a significant content of gold (table 2). The amount of metals precipitated decreases rapidly as the distance increases from the well head within the two-phase line, and low-sulfide silica scale is deposited instead of the metals. The sudden drop in fluid pressure at the well head accelerates boiling, which combines with the subsequent cooling to cause a deposition of metal (Nitta and others, 1991).

Though similar scales also have been reported from Mori (Nigorikawa) (Muramatsu and others, 1988) and Fushime (Akaku, 1988, 1990), gold deposition there is not as conspicuous in comparison with the Okuaizu geothermal area (table 2). The higher gas content in
Table 2.-Chemical composition of hydrothermal gold-bearing precipitates from some geothermal waters

[Abbreviation: ppm, parts per million. \%, percent; -, not determined]

\begin{tabular}{lcccc}
\hline & $\begin{array}{c}\text { Onuma }^{1} \\
\text { (pipeline) }\end{array}$ & $\begin{array}{c}\text { Okuaizu }^{2} \\
\text { (control valve) }\end{array}$ & $\begin{array}{c}\text { Fushime }^{3} \\
\text { (pipeline) }\end{array}$ & $\begin{array}{c}\text { Osorezan }^{4} \\
\text { (hot spring) }\end{array}$ \\
\hline $\mathrm{Au}(\mathrm{ppm})$ & 0.86 & 116 & 1.4 & 6510 \\
$\mathrm{Ag}(\mathrm{ppm})$ & 23 & 34900 & 2225 & 0.4 \\
$\mathrm{Hg}(\mathrm{ppm})$ & - & - & 0.03 & 5520 \\
$\mathrm{As}(\%)$ & - & 2.75 & - & 0.37 \\
$\mathrm{Sb}(\%)$ & 0.005 & 11.1 & 1.23 & 0.10 \\
$\mathrm{~Pb}(\%)$ & 0.001 & 13.1 & 40.16 & 0.14 \\
$\mathrm{Zn}(\%)$ & 0.004 & 13.4 & 17.15 & 0.26 \\
$\mathrm{Cu}(\%)$ & - & 16.0 & 7.79 & 0.007 \\
$\mathrm{Fe}(\%)$ & 0.35 & 1.56 & 2.92 & 3.34 \\
$\mathrm{Te}(\%)$ & - & - & - & 1.05 \\
\hline${ }^{2}$ Ichikuni and others $(1983)$ & & & \\
${ }^{2}$ Nitta and others $(1991)$ & & & \\
${ }^{2}$ Akaku (1988) & & & & \\
4 Aoki (1990) & & & & \\
\end{tabular}

the Okuaizu fluid may account for the more efficient transport and deposition of gold.

\section{Gold mineralization of the Osorezan hydrothermal system}

Geological and geochemical studies on the Osorezan hydrothermal system (Aoki, 1989, 1990: Aoki and Thompson, 1990) indicate that this is an active and evolving gold-depositing environment. Because no mining operations have been undertaken here, the entire mineralized body of this active system is preserved and allows iri-place investigation of the ore-forming processes.

The volcano Osorezan is located on the volcanic front of the northern Honshu arc. It is a long-lived composite volcano that has a caldera lake and several postcaldera extrusive events consisting of hornblende dacite. On the basis of radiometric age determination, the latest dome extrusion of dacite formed around $0.17 \mathrm{Ma}$. A younger intrusive body postdates the domes and may be responsible for today's hydrothermal activity. 
The surface expressions of hydrothermal activity focus inside the crater that formed before the domes, along north-northeast-southsouthwest and east-west fissures. Under the regional east-west compressive stress of this area, the local upward force tends to form tensional east-west fractures. This suggests that a younger intrusive body may be located at depth and serves to increase the fluid pressure by supplying heat and gas (fig. 3).

The hot spring waters at Osorezan show a wide range of salinity, $\mathrm{pH}$, and gas concentration (table 1), which indicates modification of the deep water by boiling and mixing processes. On the basis of surface sampling, the reservoir fluid is a sodium chloride water that has a neutral $\mathrm{pH}$, a high $\mathrm{H}_{2} \mathrm{~S}$ concentration, and a temperature of $220-250^{\circ} \mathrm{C}$. Oxygen and hydrogen isotopic data on the waters show a significant shift in oxygen and hydrogen away from the local meteoric water. This shift is toward the end member for hightemperature volcanic steam from calc-alkali volcanoes of an arc environment, which gives at least a 50 percent contribution of magmatic fluid to the Osorezan hydrothermal system.

Two types of neutral $\mathrm{pH}$, hot spring water are found at Osorezan; one is highly saline and gas poor, and the other is moderately saline and gas rich. The high-salinity waters ascend along the foot of the dacite domes. These waters are boiling and form sinter terraces of amorphous silica. Concentration of gold-related metals in the sinter is usually very low, which is consistent with the low $\mathrm{H}_{2} \mathrm{~S}$ content of the water. Infrequent intercalation of metalliferous bands containing colloidal Tl-Sb-As sulfides and minor gold, however, suggests the fluctuation of fluid chemistry. The interruption of gas release from a boiling hydrothermal fluid by silica sealing of fractures and subsequent refracturing, for instance, may result in a sporadic increase of $\mathrm{H}_{2} \mathrm{~S}$ and metal sulfide complexes in the hot spring water. The low concentration of gold in the surface deposit implies that gold-bearing quartz veins may be forming in the boiling zone beneath the sinter.

The other water type, which has an intermediate salinity and is rich in gas, is derived from the same source as the high-salinity water, which we judge from the consistent $\mathrm{Cl} / \mathrm{B}$ ratios. This gas-rich water discharges along permeable structures that were formed by ancient hydrothermal eruption features, which cut the lake sediments. The water contains high arsenic, together with high $\mathrm{H}_{2} \mathrm{~S}$, and precipitates arsenic sulfide and native sulfur where it mixes with oxidized and low $\mathrm{pH}$ surface water. Gold is also being precipitated along with arsenic sulfide owing to the decomposition of the sulfide complex. The concentration of gold in the hot spring precipitates reaches several tens of parts per million. Cooling by mixing with shallow water below the surface appears to prevent boiling and gas loss, which allows gold transport to the surface. Thus, two mechanisms of gold deposition are still in action and open the door to scientific investigation.

Local disturbance of sedimentary structures in the lake deposits and the circular distribution of metal anomalies have revealed the location of several hydrothermal eruption craters, despite the sediments having completely filled the depressions. The craters formed in a shallow lake floor and range from several tens to 100 meters across. The combination of the increase and release of fluid pressure that is caused by the shallow intrusion of high-temperature magma is the most probable mechanism for initiating the eruptions. In some craters, spectacular mineralization followed the eruption. Many metals were transported by the rapidly ascending deep fluid immediately following eruption, and they formed polymetallic sediments in a short time. The predominant metal species changed over time from (1) lead and zinc sulfides through (2) gold and mercury tellurides, lead-antimony sulfide, and lead-arsenic sulfide to (3) arsenic sulfide to (4) mercury sulfide to (5) sulfur. These minerals precipitated in a shrinking crater and were interlayered with clastic material. This
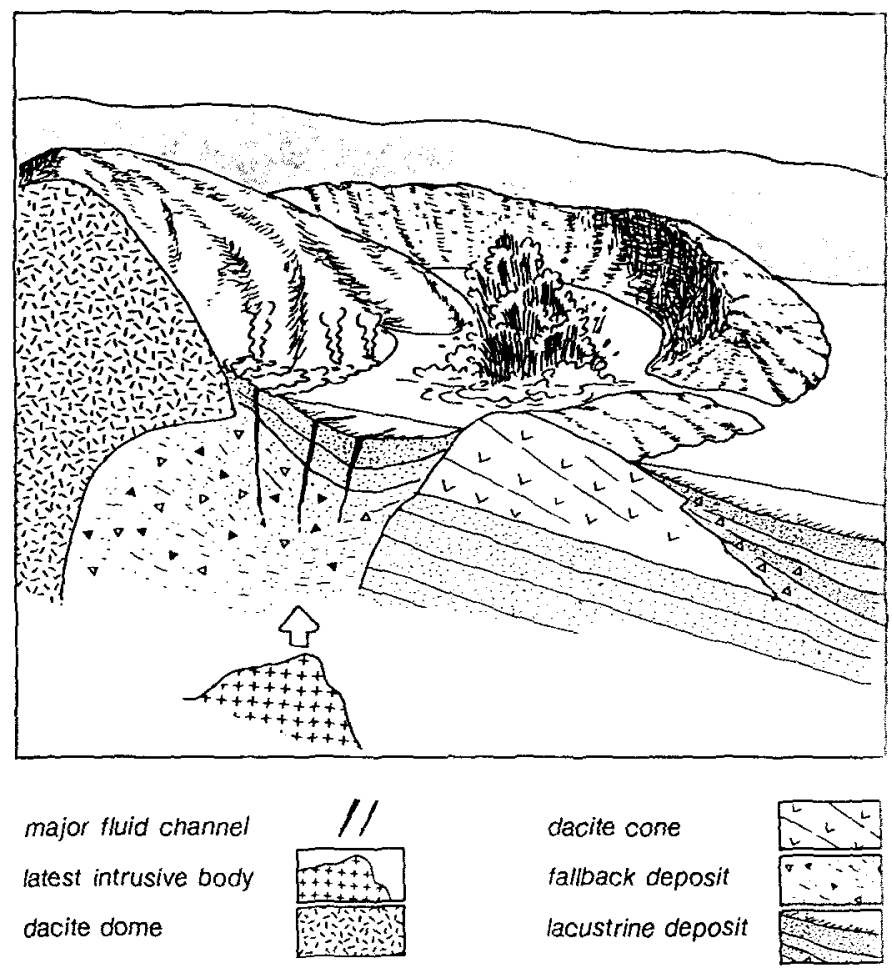

Figure 3.-Idealized cross section of the Osorezan geothermat system demonstrating a younger intrusive body as a possible trigger of east-west fracturing, hydrothermal eruptions, and the spectacular gold and base metal mineralization. During this activity, the lake water has been gradually drained by 20 meters, and the major surface expressions of the hydrothermal system are exposed.

resulted in a nearly concentric distribution pattern going from the peripheral lead and zinc sulfide zone to the central arsenic sulfide zone. Because a higher chloride concentration favors base metal transport, the gradual decrease of the flux of saline water from depth, in conjunction with increasing shallow-water dilution, resulted in the relative enrichment of gold, arsenic, antimony, and mercury. Thus, the mineralogy of hydrothermal precipitates can change over time as a result of the progressive clogging of the fluid channels as debris falls back and minerals precipitate. Whereas larger craters have abundant gold, mercury, and arsenic mineralization, the smaller ones contain mainly base metals and only minor overprints of gold and arsenic. The positive correlation of the gold/base metal ratio to the size of the crater suggests that the smaller conduit clogs in a short period and fails to record the overprint of the later stage. The mineralization in the hydrothermal etuption craters in Osorezan is unique among many mineralizing hot springs in the world, not only for the surprisingly high metal concentration (table 2) and its polymetallic nature but also for the short-term change in the composition of its mineral precipitates.

\section{Time and space distribution of gold mineralization in Japan}

The distribution of volcanic centers and related geothermal activity has not been uniform throughout time and space in Japan. The regional tectonic framework, which is linked to the subduction of oceanic plates beneath continental plates, controls the amount of 
volcanism, geothermal activity, and consequently, the potential of gold mineralization. The tectonic framework includes the dip of the subducting slabs, the oblique angle of the subduction zone, the segmented arc and arc-arc junction, and the crustal extension behind the volcanic arc.

Previously, many epithermal gold deposits were thought to have formed in the late Miocene and early Pliocene (for example, see Nishiwaki and others, 1971). However, newer radiometric age data show that many important gold deposits date from the Pleistocene, such as Hishikari in southern Kyushu (1.0-0.8 Ma; Izawa and others, 1990) (fig. 4), Seigoshi and Kawazu (Rendaiji) in the Izu Peninsula (1.6 Ma and 1.5 Ma; MITI, 1987), and Koryu near Chitose in Hokkaido (1.0 Ma; Sugaki and Isobe, 1985) (fig. 1). Significant Pleistocene gold mineralization has been found also at Hikiji, near historic workings and $13 \mathrm{~km}$ north of the Otake-Hatchobaru geothermal field (Sato and others, 1991).

Pleistocene gold deposits, together with those formed in the Pliocene, occur on the inner side of the current volcanic front (Izawa and Urashima, 1989) and appear to be concentrated near arc-arc junctions. The major middle Miocene gold deposits of Sado (15-13 Ma; Shikazono and Tsunakawa, 1982) and Konomai (13 Ma; Maeda, 1990) also occur on the inner side of today's volcanic front, although they are distant from it. The formation of the huge quartz vein system at Sado may have some relationship with the opening of the Sea of Japan in middle Miocene time.

\section{Style of gold mineralization}

Two distinct styles of epithermal mineralization are recognized as typical in the circum-Pacific region. The first type is characterized by adularia and calcite (adularia-sericite type of Heald and others, 1987). The second type is characterized by sulfate minerals such as alunite and barite (acid sulfate type).

Adularia-calcite type deposits are more important in Japan and include the deposits at Hishikari, Sado, Konomai, and Kushikino, for example. The associated volcanic rocks typically consist of andesites and dacite-rhyolites. Sinter, which often forms at the surface of high-temperature (above $180^{\circ} \mathrm{C}$ ) geothermal systems, is associated

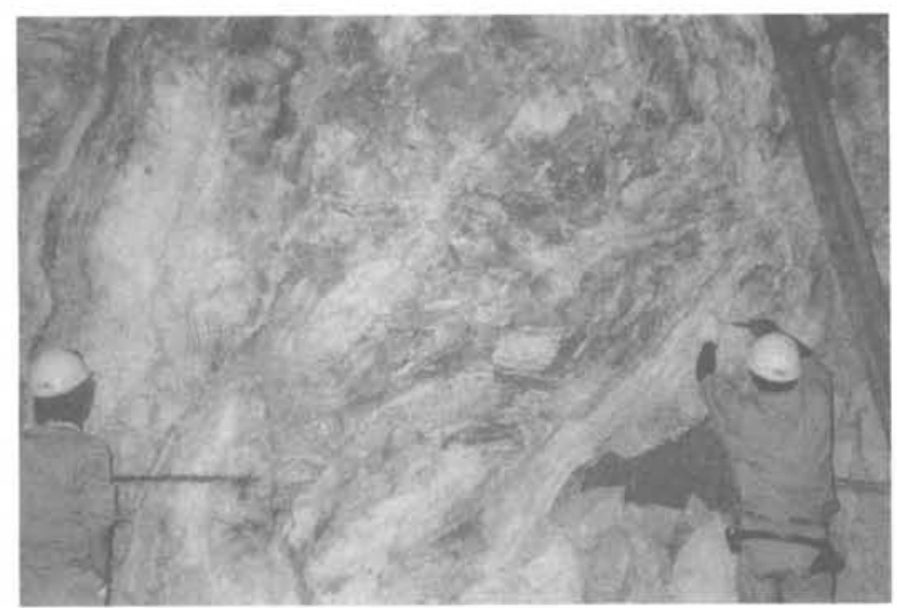

Figure 4.-Part of an 8-meter-wide quartz-adularia vein (average 50 ppm gold) underground at the Hishikari mine (25-m level W37, Zuisen no. 1 vein, looking east) in southern Kyushu. Note the collapsed structure of the vein and a cavity (lower right). commonly with this type of gold deposit. Examples include Kitano-o and Jindai (south of Konomai), Osorezan. Hikiji (near Otake), and Onoyama (near Hishikari). Chalcedonic quartz is characteristic of high-grade ores and indicates relatively low temperatures of deposition, below about $180{ }^{\circ} \mathrm{C}$. Lamellar quartz and adularia occur in high-grade zones, probably coinciding with boiling zones.

Although acid sulfate type deposits are minor both in number and in tonnage of gold produced, they form an important class of epithermal gold deposit by their distinct nature. Nansatsu-type deposits, such as Kasuga, Iwato, and Akeshi, are well-documented examples (Urashima and others, 1981). They characteristically consist of a central silicified core that is enveloped by an argillic zone of acid alteration (alunite, kaolinite, dickite, and pyrophyllite). Hornblende andesites typically are associated with gold deposits of this type. Mineralization by high-temperature acid sulfate solutions implies some direct magmatic contribution to the hydrothermal systems.

In summary, we see a broad spectrum of styles and ages of epithermal gold mineralization in Japan. This reflects the tectonic framework of the Japanese island arc in the late Cenozoic. The diversity is due to local volcanic processes, the location of the hydrothermal system in relation to the volcanic vent, and the subsequent uplift and erosion of the area. Therefore, information about geothermal activity and gold mineralization provides an insight into the evolution of this island arc.

\section{References}

Akaku, K., 1988, Geochemistry of mineral deposition from geothermal waters: Deposition processes of common minerals found in various geothermal fields and case study in the Fushime geothermal field: Chinetsu, v. 25, p. 44-61. [In Japanese.]

1990 , Geochemical study on mineral precipitation from geothermal waters at the Fushime field, Kyushu, Japan: Geothermics, v. 19, p. 455-467.

Aoki, M., 1989, Hot spring type gold deposits at Osorezan: Chishitsu News, no. 413, p. 1-5. [In Japanese.]

1990, Gold and base metal mineralization in an evolving magmatic hydrothermal system at Osorezan, northern Honshu, in Matsuhisa, Y., Aoki, M., and Hedenquist, J.W., eds., Symposium on Deep-Crust Fluids (seminar on "High-Temperature Acid Fluids and Associated Alteration and Mineralization)," 3 rd, Tsukuba, Japan, 1990, Extended abstracts: Geological Survey of Japan, p. 59-62.

Aoki, M., and Thompson, M., 1990. The Osorezan hydrothermal system, Japan: Gold bearing hot springs: Geothermal Resources Council, Transactions, v. 14, part 2, p. 1365-1369.

Fujita, Y.. 1991, A countermeasure for scaling problem in Onikobe geothermal power station, in seminar on "Scaling Problems in Utilization of Geothermal Energy," Tokyo, 1991, Proceedings: Japan Geothermal Energy Association, p. 60-68. [In Japanese.]

Goto, H., 1991, A countermeasure for scaling problems in Takigami geothermal area, in seminar on "Scaling Problems in Utilization of Geothermal Energy," Tokyo, 1991, Proceedings: Japan Geothermal Energy Association, p. 82-91. [In Japanese.]

Heald, P., Foley, N.K., and Hayba, D.O., 1987, Comparative anatomy of volcanic-hosted epithermal deposits: Acid-sulfate and adularia-sericite types: Economic Geology, v. 82, p. 1-26.

Higo, M., and Esaki, Y., 1990, Electrical update of Japan: Geothermal Resources Council, Transactions, v. 14, part I, p. 171-175.

Ichikuni, M., Tsurumi, M., and Kadoya, H., 1983, Chemistry of silica scale formed from geothermal waters: Chikyukagaku (Geochemistry), v. 17, p. 137-141. [In Japanese.]

Imai, H., Adachi, M., Takahashi, M., Yamaguchi, M., and Yashiro, K. 1988. Sulfide mineralization in Oku-Aizu geothermal field, with thi genetical relation to the epithermal gold deposits: Mining Geologv. v. 38, p. 291-301. [In Japanese.]

Izawa, E., and Urashima, Y., 1989, Quaternary gold mineralization and its geologic environments in Kyushu, Japan, in Keays, R.R., Ramsay, W.R.H., and Groves, D.I., eds., The geology of gold deposits: The perspective in 1988: Economic Geology Monograph 6, p. 233-241. 
Izawa, E., Urashima, Y., Ibaraki, K., Suzuki, R., Yokoyama, T., Kawasaki, K., Koga, A., and Taguchi, S., 1990, The Hishikari gold deposit: High-grade epithermal veins in Quaternary volcanics of southern Kyushu, Japan: Journal of Geochemical Exploration, v. 36, p.1-56.

Kodama, M., 1991, A countermeasure for scaling problems in Kirishima geothermal area, in seminar on "Scaling Problems in Utilization of Geothermal Energy," Tokyo, 1991, Proceedings: Japan Geothermal Energy Association, p. 117-120. [In Japanese.]

Maeda, H., 1990, Mineralization ages of some epithermal gold-silver veintype deposits in the Central Kitami mining district of the Kitami metallogenic province, Hokkaido, Japan: Mining Geology, v. 40, p. 17-22.

MITI, 1987, Report of regional geological structure survey, Izu area, 1986 fiscal year: Tokyo, Ministry of International Trade and Industry, $195 \mathrm{p}$. [In Japanese.]

Muramatsu, Y., Kano, S., and Kitamura, T., 1988, Formation of tetrahedrite from geothermal fluid at wells of the Nigorikawa geothermal field, southern Hokkaido: Journal of the Mineralogical Society of Japan, v. 18, p. 301-310. [In Japanese.]

Nakamura, H., Watanuki, K., Sumi, K., Suto, S., Sakai, S., and Mori, H., 1981, Geothermal fields of Tohoku, in Yuhara, K., ed., Field excursion guide to geothermal fields of Tohoku and Kyushu, Symposium on Arc Volcanism, Tokyo and Hakone, 1981: Volcanological Society of Japan and International Association of Volcanology and Chemistry of the Earth's Interior, part 1, p. 1-42.

Nishiwaki, C. Matsukuma T., and Urashima, Y., 1971, Neogene goldsilver ores in Japan: Mining Geology Special Issue no. 3, p. 409-417.

Nitta, T., Adachi, M., Takahashi, M., Inoue, K., and Abe, Y., 1991, Heavy metal precipitation from geothermal fluid of $87 \mathrm{~N}-15 \mathrm{~T}$ production well in the Okuaizu geothermal field, Tohoku District, Japan: Mining Geology, v. 41, p. 231-242. [In Japanese.]

Nitta, T., Suga, S., Tsukagoshi, S., and Adachi, M., 1987, Geothermal resources in the Okuaizu, Tohoku district, Japan: Chinetsu, v. 24, p. 340-370. [In Japanese.]

Sato, A., Nakamura, K., Nishikawa, N., Kida, S., Takenouchi, K., Miyatake, S., and Matsuki, M., 1991, Exploration for gold deposits in middle Kyushu district-Especially research results of Hikiji mine area: Mining Geology, v. 41, p. 109-125. [In Japanese.]

Shikazono, N., and Tsunakawa, H., 1982, K-Ar ages of Hosokura Pb-Zn and Sado Au-Ag vein-type deposits, northeastern part of Japan: Mining Geology, v. 32, p. 479-482. [In Japanese.]

Sugaki, A., and Isobe, K., 1985, K-Ar ages of the Sanru and Koryu mines in Hokkaido, Japan: Journal of the Japanese Association of Mineralogists, Petrologists and Economic Geologists, v. 80, p. 537-540. [In Japanese.]
Urashima, Y., Sato, M., and Sato, E., 1981, The Iwato gold ore deposits, Kagoshima Prefecture, Japan: Mining Geology Special Issue no. 10, p. 1-14. [In Japanese.]

Yoshida, Y., 1981, Chemical study on deep hot water of the Nigorikawa geothermal field: Geothermal Resources Council, Transactions, v. 5, p. 217-220.

Yuhara, K., Koga, A., Hayashi, M., and Ehara, S., 1981, Geothermal fields of Kyushu, in Yuhara, K., ed., Field excursion guide to geothermal fields of Tohoku and Kyushu, Symposium on Arc Volcanism, Tokyo and Hakone, 1981: Volcanological Society of Japan and International Association of Volcanology and Chemistry of the Earth's Interior, part 2, p. 43-66.

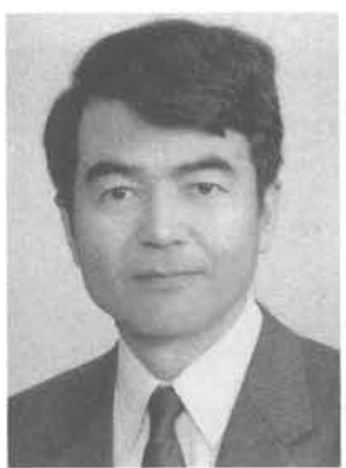

Dr. Eiji Izawa is a Professor in the Department of Mining at Kyushu University (Hakozaki, Fukuoka 812, Japan). A graduate of the International Christian University, his main research is in economic geology, particularly on epithermal gold deposits that are related to young volcanic centers. He is the Secretary of the Japan National Committee for Science of Mineral Deposits (Japan Science Council).

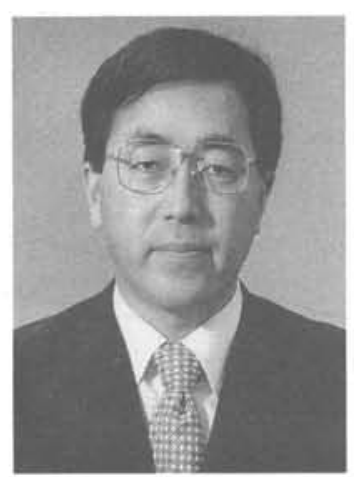

Dr. M. Aoki is a Senior Geologist with the Geological Survey of Japan (1-1-3 Higashi, Tsukuba 305, Japan). A graduate of the University of Tokyo, his scientific interests include the chemistry of hydrothermal fluids, mineralogy, and volcanic geology. As a result of combining geochemical and geological investigations of the Osorezan geothermal field in northern Japan, he discovered recently that this area is a spectacular example of active epithermal gold mineralization. 